\title{
Top BSE official forced to step down in UK
}

London

One of the key government officials in Britain's recent crisis over bovine spongiform encephalopathy (BSE) has been forced out of his job. The move came days after the completion of an official inquiry that is expected to be highly critical of the way in which the crisis was handled.

The Ministry of Agriculture, Fisheries and Food (MAFF) announced on Monday the departure of Richard Packer, its top civil servant. Packer was at the centre of events in March 1996 surrounding the announcement of evidence that BSE might be responsible for a new form of Creutzfeldt-Jakob Disease (CJD) in humans (see Nature 380, 273; 1996).

Ironically, Packer's departure coincides with new evidence - published this week in the Proceedings of the National Academy of Sciences by a team of US and UK researchers - strengthening the likelihood that newvariant CJD is caused by the same agent as that responsible for BSE in cattle.

This conclusion is based on the finding that mice injected with BSE-infected tissue develop almost identical symptoms to those of humans who develop the new-variant CJD, and over the same incubation period.

The study was conducted by researchers in the University of California, San Francisco, Institute for Neurodegenerative Diseases, whose director, Stanley B. Prusiner, won the Nobel Prize in 1997 for discovering that spongiform encephalopathies were caused by prions. The new study used human brain tissue supplied by researchers at the National CJD Surveillance Unit in Edinburgh.

Packer - who describes his recreation in Who's Who as "living intensely" — is widely known as a highly skilful, respected and, in some quarters, feared civil servant. He has a reputation for staunchly defending the interests of his ministry (and Britain's agricultural community), and standing up to ministers when he felt this necessary.

Unlike most of his predecessors, he did not graduate from Oxford or Cambridge, but joined the ministry after postgraduate studies in chemical engineering at the University of Manchester in 1967.

His departure is being described by government officials as a reflection of their desire to 'modernize' the civil service, bringing it more closely in line with the strategic priorities of the Labour government.

But some say that Packer's position has been weakened by the evidence that has emerged over the past two years of the
BSE inquiry, headed by Lord Justice Phillips.

Questioning Packer on his earlier evidence during a cross-examination this month, for example, Phillips suggested that conclusions about a possible CJD/BSE link reached by the Spongiform Encephalitis Advisory Committee in February 1996 had not been treated with sufficient urgency.

However, Phillips also expressed concern that, when it become clear that the news had major implications both for public health and for the UK beef industry, "practical decisions were taken in a great rush".

Packer has strongly defended his role in the crisis. He is reported in The Times to have told colleagues that he was only a "bit player", and that "the inquiry will show that my actions have been close to exemplary".

His departure after seven years in the top post at MAFF is likely to have major implications for the future of the ministry itself. Packer has long been a strong opponent of attempts to locate responsibility for food safety in a separate government department.

Such a move, he feared, could reduce what was until recently one of the most powerful ministries in Whitehall to little more than a Department of Rural Affairs. His departure makes that more likely. David Dickson

\section{Middle East synchrotron crosses first funding hurdle}

Paris

A scheme to build an international research centre in the Middle East using a

synchrotron donated by Germany crossed a major hurdle last week. Eleven countries in the region agreed to provide sufficient funds to pay for dismantling the machine, now located in Berlin.

The German government had demanded that the project, overseen by the United Nations Educational, Scientific and Cultural Organization (Unesco), find the money to dismantle Bessy-1, a 0.8-GeV synchrotron radiation source, by the end of the year (see Nature 399, 507-508; 1999). Bessy-1 needs to be moved to make room for the Max Planck Society's new history of science centre, and would otherwise have been scrapped.

During a meeting at Unesco headquarters in Paris last week, 11 countries each pledged US\$20,000 towards the project, known as Sesame (Synchrotron Radiation for Experimental Science and Applications in the Middle East). The United States will give another $\$ 20,000$, and Sweden will donate $\$ 5,000$. Unesco will provide the rest of the expected \$1 million needed to prepare the machine for shipping to a site yet to be decided in the Middle East.

Seven countries are vying to host the

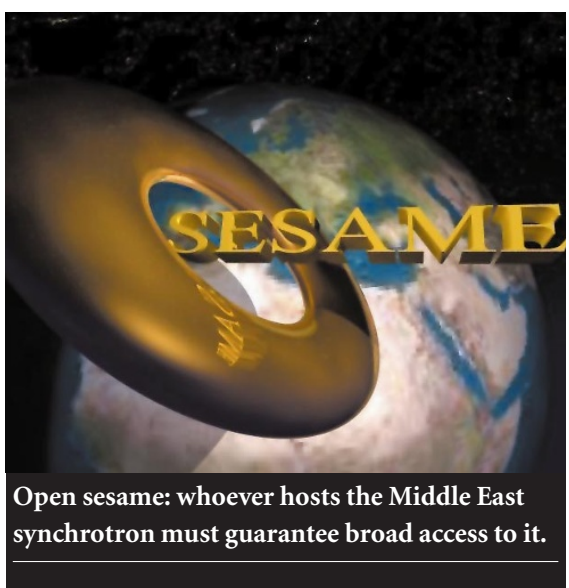

machine - Armenia, Egypt, Iran, Jordan, Oman, the Palestinian Authority and Turkey. Israel is a member of the project, but is not competing to host the light source, as this would place the source off-limits to scientists from some neighbouring countries.

The decision about which country will host the machine will be based on criteria such as a central geographical location and openness to scientists of any religion, nationality or sex. Wealthier countries may have an advantage in the bidding, since the new centre must have the financial means for its continued success.

Top candidates are said to include Jordan, the Palestinian Authority and Egypt. In contrast, Armenia, Iran and Oman may be too remote to provide easy access for countries in the area. And a few countries, such as Iran, have not received guarantees from their governments that the centre could guarantee broad access.

The next major hurdle will be to raise around $\$ 100$ million to build the new facility, to provide running costs for the first couple of years, and to upgrade the machine. An upgrade would include extending the machine's spectral range to $20-25 \mathrm{keV}$ to provide hard X-rays, which are especially useful for protein crystallography and environmental studies.

Most of this sum will probably need to be raised outside the region, perhaps from large sources of funding such as the United States, Europe and perhaps even Japan.

"The money already coming to the region from other countries is very substantial, and we need only a few per cent of this," says Herwig Schopper, former director-general of the European Laboratory for Particle Physics (CERN) and president of the project's interim council. Heather McCabe 